\title{
Pengaruh Model Pembelajaran Snowball Throwing Terhadap Kemampuan Komunikasi Matematis Siswa
}

\author{
Suliswa ${ }^{1)}$, Rosmaiyadi ${ }^{2)}$, Buyung ${ }^{3)}$ \\ 1) STKIP Singkawang, Singkawang, Indonesia \\ E-mail: suliswa65@gmail.com \\ 2) STKIP Singkawang, Singkawang, Indonesia \\ E-mail: rosmaiyadialong@gmail.com \\ 3) STKIP Singkawang, Singkawang, Indonesia \\ E-mail:21.buyung@gmail.com
}

\begin{abstract}
Abstrak. Tujuan penelitian ini untuk mengetahui pengaruh model pembelajaran snowball throwing terhadap kemampuan komunikasi matematis siswa. Jenis penelitian ini adalah True Eksperimental dengan desain penelitian Posttest Only Control Desain. Populasi dalam penelitian ini adalah seluruh siswa kelas XI IPS SMA Negeri 6 Singkawang. Instrument yang digunakan dalam penelitian ini adalah tes kemampuan komunikasi matematis siswa, angket motivasi, lembar observasi aktivitas. Teknik analisis data dalam penelitian ini sebagai berikut: 1) Untuk menjawab sub masalah 1 menggunakan uji $t$ independen; 2) Untuk menjawab sub masalah 2 menggunakan rumus effect size; 3) Untuk menjawab sub masalah 3 dianalisis berdasarkan skala likert; 4) Untuk menjawab sub masalah 4 dihitung berdasarkan rumus persentase aktivitas. Berdasarkan hasil analisis disimpulkan bahwa: 1) Terdapat perbedaan kemampuan komunikasi matematis siswa antara yang menggunakan model pembelajaran snowball throwing dengan yang tidak menggunakan model pembelajaran snowball throwing dengan nilai thitung 7,9 dan ttabel 2,009 yaitu 7,9> 2,0009; 2) Terdapat pengaruh model pembelajaran snowball throwing terhadap kemampuan komunikasi matematis siswa, dengan effect size sebesar 1,83 yang tergolong tinggi. 3) Terdapat pengaruh model pembelajaran snowball throwing terhadap motivasi siswa, dengan rata - rata motivasi belajar siswa yaitu 79,90 kategori sangat baik; 4) Terdapat pengaruh model pembelajaran snowball throwing terhadap aktivitas siswa, persentase aktivitas siswa untuk pada dua pertemuan adalah 63,98\% kategori tinggi.
\end{abstract}

Kata Kunci: Pembelajaran Snowball Throwing, Kemampuan Komunikasi Matematis, Motivasi Belajar Siswa, Aktivitas Belajar Siswa

\section{PENDAHULUAN}

National Council of Teacher Mathematics tahun 2000 mengungkapkan terdapat 5 standar proses dalam pembelajaran matematika diantaranya kemampuan pemecahan masalah, penalaran, kemampuan komunikasi matematis, kemampuan mengkoneksi, dan kemampuan representasi matematis. Kemampuan komunikasi merupakan standar yang memilki peran penting. Komunikasi matematika tidak hanya diartikan dengan pemahaman matematika, namun sangat terkait dengan peningkatan kemampuan memecahkan masalah (Wibowo, 2010). Kemampuan siswa dalam berkomunikasi dengan menggunakan matematika sangat penting untuk diungkapkan. Untuk mengkomunikasikan matematika ada beberapa aspek yang harus diperhatikan yaitu aspek merepresentasi, merekonstruksi, dan kerjasama.

Komunikasi menjadi bagian yang esensial dari matematika dan pendidikan (Nurdina, 2013). Komunikasi adalah cara untuk berbagi (sharing) gagasan dan mengklarifikasi pemahaman. Melalui komunikasi, gagasan gagasan menjadi objek - objek refleksi, penghalusan, diskusi dan perombakan. Proses komunikasi membantu makna dan kelanggengan untuk gagasan - gagasan, serta menjadikan gagasan - gagasan itu diketahui publik (Rachmayani, 2014). Pendapat ini mengisyaratkan pentingnya komunikasi dalam pembelajaran matematika.

Komunikasi matematika merupakan suatu peristiwa saling hubungan atau dialog yang terjadi dalam suatu lingkungan kelas dimana terjadi pengalihan pesan balik secara tertulis maupun lisan yang berisi tentang materi matematika yang dipelajari di kelas. Indikator kemampuan komunikasi matematis menurut adalah: 1) Kemampuan menjelaskan suatu persoalan secara tertulis dalam bentuk gambar (menggambar); 2) Kemampuan menyatakan suatu persoalan secara tertulis dalam bentuk model matematika (ekspresi); 3) Kemampuan menjelaskan ide atau situasi dari suatu gambar yang diberikan dengan kata-kata sendiri dalam bentuk tulisan (menulis) (Husna, 2013). 


\section{- - - Jurnal Pendidikan Matematika Indonesia \\ Volum 2 Nomor 1 bulan Maret 2017. Page 37-41 \\ p-ISSN: 2477-5967 e-ISSN: 2477-8443}

Pengembangan komunikasi menjadi salah satu tujuan pembelajaran matematika dan menjadi salah satu standar kompetensi lulusan dalam bidang matematika seperti yang diungkapkan oleh Ali Mahmudi (Marlina, 2013). Melalui pembelajaran matematika, siswa diharapkan dapat mengkomunikasikan gagasan dengan simbol, tabel, diagram, atau media lain untuk memperjelas keadaan atau masalah.

Dalam mengajarkan matematika, pembelajaran di kelas hampir selalu dilaksanakan secara konvensional. Akibatnya, siswa pada umumnya dapat melakukan berbagai perhitungan matematis, tetapi kurang menunjukkan hasil yang menggembirakan terkait penerapannya dalam kehidupan sehari-hari khususnya kemampuan komunikasi matematis (Nurhayati, Sugiatno, \& Hamdani, 2013: 2).

Hasil penelitian terdahulu menyatakan bahwa dari tes kemampuan komunikasi matematis siswa hanya sedikit yang mencapai ketuntasan. Dengan demikian kemampuan komunikasi matematis siswa MTs. Negeri Legok tergolong rendah (Mardhiyanti, 2011)

Hal ini sejalan dengan hasil prariset yang diberikan peneliti dengan memberikan tes kemampuan komunikasi matematis. Prariset yang dilakukan di SMA Negeri 6 Singkawang kelas XI IPS 1 untuk mengetahui kemampuan awal tentang komunikasi matematis siswa. Soal prariset yang diberikan bejumlah 3 soal dalam bentuk essay yang masing-masing mewakili indikator kemampuan komunikasi matematis siswa. Dari hasil prariset tersebut dapat dinyatakan bahwa kemampuan komunikasi siswa di SMA Negeri 6 Singkawang masih rendah.

Berdasarkan hasil wawancara peneliti dengan guru matematika di SMA Negeri 6 Singkawang masalah yang terjadi di kelas adalah siswa kurang termotivasi dalam mengikuti pembelajaran matematika. Dari keterangan guru matematika SMA Negeri 6 Singkawang, untuk materi komposisi fungsi dan fungsi invers aktivitas siswa tergolong rendah. Hal tersebut berpengaruh pada nilai ulangan harian siswa tahun ajaran lalu yang telah mempelajari materi komposisi fungsi dan fungsi invers dari 29 siswa, hanya 12 orang yang mencapai ketuntasan, 17 orang tidak mencapai ketuntasan. Kesulitan yang dialami siswa pada materi komposisi fungsi dan invers fungsi adalah dalam mengoperasikan komposisi fungsi. Padahal guru yang mengajar sudah berpengalaman dan sesuai dengan bidangnya. Tidak hanya itu buku panduan yang digunakan dalam pengajaran sudah sesuai dengan standar yang ditentukan dari Dinas Pendidikan. Begitu juga siswa sudah dibantu dengan buku panduan LKS.

Pada tahun ajaran sebelumnya, materi komposisi fungsi dan fungsi invers diajarkan dengan pembelajaran konvensional yaitu metode ceramah. Kegiatan siswa hanya memperhatikan guru, tidak terlalu merespon penjelasan guru, dan melakukan kegiatan pembelajaran hanya berdasarkan perintah guru saja. Hanya beberapa siswa yang bertanya atau menanggapi pertanyaan atau pernyataan guru. Oleh karena itu, peneliti ingin menerapkan model pembelajaran snowball throwing sebagai alternatif pembelajaran yang dapat memacu aktifitas siswa serta dapat mengembangkan kemampuan komunikasi matematis siswa. Berdasarkan wawancara peneliti dengan guru matematika kelas X I di SMA Negeri 6 Singkawang mengatakan bahwa dirinya belum pernah menerapkan model pembelajaran snowball throwing pada pembelajaran matematika dan harapan beliau adalah dengan diterapkannya model pembelajaran ini dapat meningkatkan hasil belajar siswa terutama pada materi fungsi komposisi dan fungsi invers.

Pemilihan model pembelajaran yang tepat merupakan bagian yang penting bagi guru sebelum memberikan pelajaran di kelas. Zuldafrial mengatakan bahwa pembelajaran yang dapat diterapkan agar proses pembelajaran dapat berjalan efektif dan lebih mengaktifkan siswa adalah pembelajaran berkelompok (Susanti, 2013). Tujuan utama pembelajaran berkelompok adalah supaya anak bersosialisasi dan bekerjasama. Schmuck menyatakan bahwa belajar kelompok dapat melatih dan membiasakan siswa saling berbagi pengetahuan, pengalaman, tugas, dan tanggung jawab (Hamdani, 2011). Saling berbagi pengetahuan dan pengalaman merupakan bagian dari komunikasi. Oleh karena itu, pembelajaran kelompok yang bisa melatih kemampuan komunikasi matematis siswa merupakan solusi yang tepat dalam mengurangi pembelajaran yang hanya berpusat pada guru.

Model pembelajaran Snowball Throwing merupakan model pembelajaran tipe kooperatif yang dapat melatih kemampuan komunikasi siswa. Menurut Widodo metode snowball throwing merupakan "gelundungan atau lemparan bola salju berisi pertanyaan yang diisi dan dilemparlemparkan oleh siswa kepada temannya, yang terkena lemparan wajib untuk menjawab pertanyaan yang tersedia di dalamnya" (Januwardana, 2014). Kegiatan melempar bola pertanyan ini akan membuat kelompok menjadi dinamis, karena kegiatan siswa tidak hanya berpikir, menulis, bartanya, atau berbicara. Akan tetapi mereka juga melakukan aktivitas fisik yaitu menggulung kertas dan melemparkannya pada siswa lain. Dengan demikian, tiap anggota kelompok akan mempersiapkan diri karena pada gilirannya mereka harus menjawab pertanyaan dari temannya yang terdapat dalam bola kertas.

Penggunaan pendekatan pembelajaran snowball throwing dalam meningkatkan keaktifan belajar siswa ini dirasakan cukup efektif karena siswa akan terlatih untuk mengemukakan gagasan dan perasaan secara cerdas dan kreatif, serta mampu menemukan dan menggunakan kemampuan analitis dan imajinatif yang ada dalam dirinya untuk menghadapi berbagai persoalan yang muncul dalam kehidupan sehari-hari. Pada materi komposisi fungsi dan fungsi invers ini peneliti membahas pada pokok bahasan aljabar fungsi.

Hasil penelitian menunjukkan bahwa pembelajaran dengan model pembelajaran Snowball Throwing pada materi Statistika dapat meningkatkan kemampuan komunikasi matematis siswa (Sari, 2013). Hal ini di lihat dari hasil sebelum tindakan diberikan dan setelah tindakan diberikan mengalami peningkatan yang cukup signifikan. 


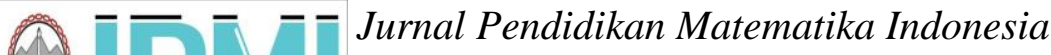 \\ Volum 2 Nomor 1 bulan Maret 2017. Page 37-41 \\ p-ISSN: 2477-5967 e-ISSN: 2477-8443}

\section{METODE}

Metode yang digunakan dalam penelitian ini adalah penelitian eksperimen. Bentuk penelitian yang digunakan dalam penelitian ini adalah True Experimental dengan desain penelitian yaitu Posttest Only Control Desain. Populasi dalam penelitian ini adalah seluruh siswa kelas XI IPS SMA Negeri 6 Singkawang yang terdiri dari dua kelas yaitu kelas XI IPS 1, dan kelas XI IPS 2. Teknik pengambilan sampel yang digunakan dalam penelitian ini adalah sampling jenuh. Sampel dalam penelitian ini adalah kelas eksperimen XI IPS 1 dan kelas kontrol XI IPS 2 SMA Negeri 6 Singkawang.

Teknik pengumpulan data dalam penelitian ini adalah teknik tes kemampuan komunikasi matematis, teknik observasi, dan teknik angket. Instrumen pengumpul data dalam penelitian ini yaitu: (a) tes kemampuan komunkasi matematis dalam berntuk essay; (b) lembar observasi aktivitas, dan; (c) lembar angket motivasi.

Teknik analisis data dalam penelitian ini adalah sebagai berikut: (a) untuk menjawab sub masalah 1, yaitu mengetahui perbedaan kemampuan komunikasi matematis siswa antara yang menggunakan model pembelajaran snowball throwing dengan yang tidak menggunakan model pembelajaran snowball throwing pada materi komposisi fungsi dan fungsi invers kelas XI IPS SMA Negeri 6 Singkawang, maka menggunakan independent t-test; (b) untuk menjawab sub masalah 2 yaitu untuk mengetahui pengaruh model pembelajaran snowball throwing terhadap komunikasi matematis siswa pada materi komposisi fungsi dan fungsi invers kelas XI IPS SMA Negeri 6 Singkawang menggunakan rumus effect size; (c) untuk menjawab sub masalah 3 yaitu untuk mengetahui pengaruh model pembelajaran snowball throwing terhadap motivasi pada materi komposisi fungsi dan fungsi invers kelas XI IPS SMA Negeri 6 Singkawang, maka skor dianalisis berdasarkan skala likert; (d) untuk menjawab sub masalah 4 , yaitu untuk mengetahui pengaruh model pembelajaran snowball throwing terhadap aktivitas siswa pada materi komposisi fungsi dan fungsi invers kelas XI IPS SMA Negeri 6 Singkawang, maka dihitung berdasarkan persentase aktivitas siswa pada lembar observasi.

\section{HASIL DAN PEMBAHASAN}

Hasil penelitian ini diperoleh dari beberapa data yang telah dianalisis. Adapun hasil yang diperoleh dari penelitian ini yaitu, hasil tes kemampuan komunikasi matematis siswa pada model pembelajaran snowball throwing, hasil analisis angket motivasi siswa terhadap model pembelajaran snowball throwing, dan hasil observasi aktivitas siswa menggunakan model pembelajaran snowball throwing. Hasil tes kemampuan komunikasi matematis siswa diperoleh dari hasil perhitungan nilai posttest. Adapun hasil perhitungan nilai posttest siswa kelas eksperimen dan kelas kontrol disajikan pada Tabel 1 sebagai berikut.
TABEL I

REKAPITULASI HASIL POSTTEST KELAS EKSPERIMEN DAN KELAS KONTROL

\begin{tabular}{ccc} 
& \multicolumn{2}{c}{ EKSPERIMEN DAN KELAS KONTROL } \\
\hline Keterangan & $\begin{array}{l}\text { Kelas } \\
\text { Eksperimen }\end{array}$ & $\begin{array}{c}\text { Kelas } \\
\text { Kontrol }\end{array}$ \\
\hline Varians & 186,20 & 292,24 \\
$F_{\text {hitung }}$ & & 1,57 \\
$F_{\text {tabel }}$ & 1,85 & \\
\hline
\end{tabular}

Secara deskripsi terlihat data skor posttest kelompok kelas eksperimen dan kelas kontrol tidak sama. Maka dari itu untuk selanjutnya akan dilakukan uji perbedaan dua rerata.Selanjutnya dilakukan uji perbedaan rata - rata skor posttest kelas eksperimen dan kelas kontrol, namun sebelumnya rata - rata skor posttest kelas eksperimen dan kelas kontrol dilakukan uji normalitas dan homogenitas variansi data. Adapun rekapitulasi hasil uji normalitas data posttest untuk kelas eksperimen dan kontrol, dapat dilihat pada Tabel II berikut.

TABEL II

REKAPITUlasi Uji NORMALITAS DATA POSTTEST

\begin{tabular}{ccccc}
\hline Keterangan & $\sum x_{1}$ & $\sum x_{2}$ & $\sum\left(x_{1}-\overline{x_{1}}\right)^{2}$ & $\sum\left(x_{1}-\overline{x_{2}}\right)^{2}$ \\
\hline Skor & 2365 & 1365 & 5586,03 & 8475 \\
\hline$t_{\text {hitung }}$ & & & 7,9 \\
$t_{\text {tabel }}$ & & 2,0
\end{tabular}

Pada Tabel II di atas, terlihat bahwa $x^{2}$ hitung kelas eksperimen 3,262 dengan $x^{2}$ tabel 7,81 diketahui 7,81> 3,262 , maka dapat disimpulkan bahwa data posttest kelas eksperimen berdistribusi normal. Untuk kelas kontrol nilai $x^{2}$ hitung 1,71 dengan $x^{2}$ tabel 7,81 diketahui bahwa 7,81 $>1,71$, maka dapat disimpulkan bahwa data posttest kelas kontrol berdistribusi normal. Setelah dilakukan pengujian normalitas terhadap posttest kelas eksperimen dan kelas kontrol selanjutnya dilakukan uji homogenitas variansinya. Adapun rekapitulasi hasil posttest varians kelas eksperimen dan kelas kontrol dapat dilihat pada Tabel III sebagai berikut.

TABEL III

REKAPITUlasi HASIL POSTTEST VARIANS KELAS EKSPERIMEN DAN KELAS KONTROI

\begin{tabular}{ccc}
\hline Keterangan & $\begin{array}{c}\text { Kelas } \\
\text { Eksperimen }\end{array}$ & $\begin{array}{c}\text { Kelas } \\
\text { Kontrol }\end{array}$ \\
\hline Rata - Rata & 76.29 & 45.50 \\
Standar Deviasi & 13.42 & 16.81 \\
\hline
\end{tabular}

Berdasarkan Tabel 3 terlihat bahwa varians kelas eksperimen adalah 186,20 dan varians kelas kontrol adalah 292,24 sehingga diperoleh $F_{\text {hitung }} 1,57$ dan $F_{\text {tabel }} 1,85$, 
maka dapat disimpulkan bahwa $F_{\text {hitung }}<F_{\text {tabel }}$ Hal ini berarti varians kedua data posttest adalah homogen.

Selanjutnya dilakukan analisis statistik pengujian pebedaan dua rata - rata sampel. Kriteria pengujian Ha diterima jika $t_{\text {hitung }}>t_{\text {tabel }}$. Adapun rekapitulasi hasil perhitungan posttest dari 31 siswa kelas eksperimen dan 30 siswa kelas kontrol dapat dilihat pada Tabel IV sebagai berikut.

TABEL IV

REKAPITUlasi PERHITUNGAN DUA RATA - RATA KELAS EKSPERIMEN DAN KELAS KONTROL

\begin{tabular}{|c|c|c|}
\hline & Kelas Eksperimen & Kelas Kontrol \\
\hline$x^{2}$ hitung & 3,262 & 1,719 \\
\hline$x^{2}$ tabel & \multicolumn{2}{|c|}{7,81} \\
\hline Keterangan & Normal & Normal \\
\hline
\end{tabular}

Berdasarkan Tabel IV dan kriteria pengujian di atas terlihat bahwa $t_{\text {hitung }} 7,9$ dan $t_{\text {tabel }} 2,0$, karena $t_{\text {hitung }}$ lebih besar dari $t_{\text {tabel }}$ maka Ha diterima, artinya terdapat perbedaan kemampuan komunikasi matematis siswa kelas eksperimen dan kelas kontrol. Sejalan dengan hal tersebut penelitian menunjukan bahwa kemampuan komunikasi matematis siswa lebih baik setelah diberikan perlakuan dengan model pembelajaran snowball throwing dibanding dengan pembelajaran secara konvensional (Putri, 2013).

Selanjutnya untuk mengetahui seberapa besar pengaruh model pembelajaran snowball throwing terhadap kemampuan komunikasi matematis siswa, maka digunakan rumus Effect Size. Berdasarkan perhitungan diperoleh effect size 1,83. Berdasarkan kriteria effect size maka $E_{s}=1,83$ berada pada skala $E_{s}>80$ yang artinya kriterianya tergolong tinggi. Hal ini berarti terdapat pengaruh model pembelajaran snowball throwing terhadap kemampuan komunikasi matematis siswa. Sejalan dengan hal tersebut penelitian yang dilakukan oleh (Supardi, 2011) menunjukan bahwa terjadi perubahan yang signifikan kemampuan komunikasi matematis siswa setelah diberikan perlakuan dengan model pembelajaran snowball trowing.

Motivasi siswa diperoleh melalui penyebaran angket setelah kegiatan pembelajaran menggunakan model pembelajaran snowball throwing. Model pembelajaran dikatakan berpengaruh terhadap motivasi jika rata - rata motivasi siswa berada pada kategori tinggi atau sangat tinggi. Adapun rekapitulasi hasil angket motivasi siswa dapat dilihat pada Tabel V sebagai berikut.

TABEL V

REKAPITULASI HASIL ANGKET MOTIVASI SISWA

\begin{tabular}{cc}
\hline Keterangan & Skor \\
\hline Rata - Rata & 75,81 \\
Kriteria & Sangat Tinggi \\
\hline
\end{tabular}

Berdasarkan Tabel $\mathrm{V}$ dan kriteria di atas diketahui bahwa rata - rata motivasi siswa 75,81 , dengan kriteria sangat tinggi. Maka dapat disimpulkan bahwa terdapat pengaruh model pembelajaran snowball throwing terhadap motivasi siswa. Sejalan dengan hal tersebut penelitian lain menunjukkan bahwa pembelajaran dengan metode snowball throwing dapat menimbulkan reaksi yang memicu peningkatan motivasi belajar siswa, dimana hasil perhitungan angket menunjukan motivasi siswa tinggi setelah diberikan model pembelajaran snowball throwing (Januwardana, 2014)]. Selain itu motivasi yang tinggi juga disertai oleh hasil belajar siswa yang tinggi.

Observasi yang dilakukan dalam penelitian ini adalah untuk mengetahui pengaruh model pembelajaran snowball throwing terhadap aktivitas siswa. Observasi dilakukan dengan menggunakan lembar observasi yang telah divalidasi oleh ahli. Adapun rekapitulasi data hasil observasi pada pertemuan pertama dan kedua dapat dilihat pada Tabel VI Sebagai berikut.

TABEL VI

REKAPITUlasi Hasil OBSERVASI AKTIVITAS Siswa

\begin{tabular}{ccc}
\hline & $\begin{array}{c}\text { Persentase aktivitas } \\
\text { Pertemuan 1 }\end{array}$ & $\begin{array}{c}\text { Persentase aktivitas } \\
\text { Pertemuan 2 }\end{array}$ \\
\hline $\begin{array}{c}\text { Persentase } \\
\text { Total } \\
\text { Kriteria }\end{array}$ & $62,53 \%$ & $63,98 \%$ \\
\hline
\end{tabular}

Berdasarkan Tabel VI dan kriteria di atas diperoleh persentasi aktivitas siswa secara keseluruhan pada pertemuan pertama adalah $62.53 \%$ dengan kriteria aktivitas baik, dan persentasi aktivitas siswa secara keseluruhan pada pertemuan kedua adalah $63.98 \%$ dengan kriteria aktivitas baik. Karena persentase aktivitas siswa pada kedua pertemuan adalah baik, maka dapat disimpulkan bahwa terdapat pengaruh model pembelajaran snowball throwing terhadap aktivitas siswa. Sejalan dengan hal tersebut penelitian yang dilakukan oleh (Budiarjo, 2011) menunjukan bahwa aktivitas siswa meningkat setelah diterapkan model pembelajaran snowball throwing dengan 3 siklus. Hal ini berarti model pembelajaran snowball throwing efektif untuk meningkatkan aktivitas belajar siswa.

\section{KESIMPULAN}

1. Terdapat perbedaan kemampuan komunikasi matematis siswa dengan model pembelajaran snowball throwing dan pembelajaran konvensional pada materi komposisi fungsi dan fungsi invers kelas XI IPS SMA Negeri 6 Singkawang.

2. Terdapat pengaruh model pembelajaran snowball throwing terhadap kemampuan komunikasi matematis siswa pada materi komposisi fungsi dan fungsi invers kelas XI IPS SMA Negeri 6 Singkawang.

3. Terdapat pengaruh model pembelajaran snowball throwing terhadap motivasi siswa pada materi 
komposisi fungsi dan fungsi invers kelas XI IPS SMA Negeri 6 Singkawang.

4. Terdapat pengaruh model pembelajaran snowball throwing terhadap aktivitas siswa pada materi komposisi fungsi dan fungsi invers kelas XI IPS SMA Negeri 6 Singkawang.

\section{UCAPAN TERIMAKASIH}

Penulis mengucapkan terima kasih kepada seluruh dosen Pendidikan Matematika STKIP Singkawang, kepada Ketua STKIP Singkawang Drs. Andi Mursidi, M.Si. yang telah memberikan arahan dan bimbingan dalam penulisan artikel hasil penelitian ini.

\section{DAFTAR PUSTAKA}

Fahradina, Nova. (2014). Peningkatan Kemampuan Komunikasi Matematis dan Kemandirian Siswa dengan Menggunakan Model Investigasi Kelompok. Jurnal Didaktik Matematika ISSN: 2355-4185

Hamdani. (2011). Strategi Belajar Mengajar. Bandung: Pustaka Setia.

Husna, dkk. (2013). Peningkatan Kemampuan Pemecahan Masalah Dan Komunikasi Matematis Siswa Sekolah Menengah Pertama Melalui Model Pembelajaran Kooperatif Tipe Think-Pair-Share (Tps). Jurnal Peluang, Volume 1, Nomor 2, April 2013, ISSN: $2302-$ 5158

Januwardana, I Gd Arta dkk. (2014). Pengaruh Metode Snowball Throwing Berbantuan Media Sederhana Terhadap Hasil Belajar Matematika Siwa Kelas V SD Gugus 1 Kuta Bandung. Jurnal Mimbar PGSD Universitas Pendidikan Ganesha Jurusan PGSD (Vol: 2 No: 1 Tahun 2014)

Lubis, Kun Marlina. (2011). Peningkatan Aktivitas Pembelajaran Hidrosfer Dan Dampaknya Terhadap Kehidupan Melalui Tindakan Guru Inovatif Pada Kelas X Di Sma Negeri 1 Semarang. Jurnal Geografi vol 8.

Mardhiyanti, devi dkk. (2011). Pengembangan Soal Matematika Model Pisa Untuk Mengukur Kemampuan Komunikasi Matematis Siswa Sekolah Dasar. Jurnal Matematika Unsri.

Marlina, Fitria. (2013). Peningkatan Kemampuan Komunikasi Matematika Melalui Strategi Pembelajaran Cooperative Script Pada Siswa Kelas Vii Semester Genap SMP Muhammadiyah 10 Surakarta Tahun 2011/2012. Jurnal FKIP Matematika UMS

Nurdina, Tya. (2013). Kemampuan Komunikasi Siswa Dalam Matematika pada Materi Segitiga . Jurnal Pendidikan Matematika UNTAN vol.3
Nurhayati, Sugiatno, \& Hamdani. (2013). Mengatasi Kesulitan Komunikasi Matematis Siswa SMA Menggunakan Wawancara Klinis Berbantuan Tablet Berbasis Multi Representasi. Jurnal Pendidikan dan Pembelajaran, Volum 2 Nomor 9, September 2013.

Rachmayani, Dwi. (2014). Penerapan Pembelajaran Reciprocal Teaching Untuk Meningkatkan Kemampuan Komunikasi Matematis dan Kemandirian Belajar Matematika Siswa. Jurnal PENDIDIKAN UNSIKA ISSN 2338-2996 Volume 2 Nomor 1

Sari, Ika. (2013). Peningkatan Kemampuan komunikasi matematis Siswa dengan Menggunakan Metode pembelajaran Snowball Throwing pada Materi Statistika kelas X SMA Swasta Rizki Ananda Medan. Skripsi Matematika UNIMED

Siallagan, Ardin. (2012). Penerapan Model Pembelajaran Snowball Throwing dalam Meningkatkan Hasil Belajar Siswa. Jurnal JUPIIS Volume 4

Susanti. (2013). Pengaruh Model Pembelajaran Kooperatif Tipe Make A Match Terhadap Hasil Belajar Siswa Pada Materi Pertidaksamaan Linear Satu Variabel Di Kelas VII Nurul Islam. Skripsi STKIP PGRI Pontianak: tidak diterbitkan.

Wibowo, Anggit. (2010). Penerapan Pembelajaran dengan Teknik Probing dalam Kelompok Kecil untuk Meningkatkan Kemampuan Komunikasi pada. Skripsi Pendidikan Matematika Universitas Muhammadiyah Surabaya 